\title{
高熱電変換性能ハーフホイスラー化合物の合金組成
}

\author{
山本 佳亮 ${ }^{* 1}$ ，志賀 拓麿*1，塩見 淳一郎 ${ }^{* 2}$
}

\section{Alloy composition of half-Heusler compounds for high thermoelectric performance}

\author{
Keisuke YAMAMOTO $^{* 1}$, Takuma SHIGA ${ }^{* 1}$ and Junichiro SHIOMI ${ }^{* 2}$ \\ ${ }^{*},{ }^{* 2}$ Department of Mechanical Engineering, The University of Tokyo \\ 7-3-1 Hongo, Bunkyo-ku, Tokyo 113-8656, Japan \\ ${ }^{*}$ Japan Science and Technology Agency, PRESTO \\ 4-1-8 Honcho, Kawaguchi-shi, Saitama 332-0012, Japan
}

\section{Received 1 December 2014}

\begin{abstract}
We performed first-principles-based calculations of density of states, electrical conductivity, Seebeck coefficient, and thermal conductivity of a p-type half-Heusler compounds $(\mathrm{ZrCoSb})$ to identify the alloy composition that gives rise to a high thermoelectric figure-of-merit. The strategy here is to substitute constituent atoms of $\mathrm{ZrCoSb}$ with lighter or heavier homologous element to reduce thermal conductivity without appreciably altering electrical properties. The density-of-states calculations reveal that substitution of $\mathrm{Sb}$ does not singnificantly alter the electronic states near Fermi level. The small influence on electrical properties was also confirmed by performing calculations for $\mathrm{ZrCoBi}$, where the power factor is slightly larger than that of $\mathrm{ZrCoSb}$. The effect of alloying on thermal conductivity reduction was quantified by equilibrium molecular dynamics simulations of $\mathrm{ZrCoSb}_{1-x} \mathrm{Bi}_{x}$ with force fields obtained from first principles. With increasing alloy fraction $x$, thermal conductivity rapidly reduces to less than $15 \%$ of that of $\mathrm{ZrCoSb}$ and nearly saturates above $x \sim 20 \%$, suggesting $\mathrm{ZrCoSb}_{0.8} \mathrm{Bi}_{0.2}$ to be a reasonable alloy composition for high thermoelectric performance.
\end{abstract}

Key words : Half-Heusler compound, Thermoelectric material, Thermal conductivity, Molecular dynamics

\section{1. 緒言}

熱電変換は動作部や化学反応を必要としないことから，クリーンな発電技術として注目されている. 熱電変換 材料の無次元性能指数は $Z T=S^{2} \sigma T / \kappa$ と表され, ゼーベック係数 $S$ および電気伝導率 $\sigma$ が高く, 熱伝導率 $\kappa$ が低い 材料が望まれる.ここで $T$ は材料の平均温度である. 高いパワーファクター $\left(S^{2} \sigma\right)$ を示す材料として，近年ハー フホイスラー化合物が注目されている.ハーフホイスラー化合物は 3 元系の化合物で XYZ といら組成式をもち, 3 原子から成る基本構造の面心立方格子を形成する。図 1 はその慣用単位胞を示しており, 元素 $\mathrm{X}$ と $\mathrm{Z}$ は合わせ て塩化ナトリウム型構造を形成し, 元素 Y は 8 個の単純立方格子のうち, 4 個の体心位置にだけ存在している. 基本単位胞には各原子が 1 個ずつ含まれ, 慣用単位胞は基本単位胞が 4 個, 合計 12 個の原子から成る. ハーフホ イスラー化合物は基本単位胞の総価電子数が 18 のときにバンドギャップが比較的小さく, 大きなパワーファクタ 一を示すことが知られている（Sekimoto, et al., 2007;Poon, 2001）。さらに，優れた熱安定性と機械的特性を有する

No.14-00652 [DOI: 10.1299/transjsme.14-00652], J-STAGE Advance Publication date : 12 March, 2015

*1 東京大学大学院工学系研究科（广113-8656 東京都文京区本郷 7-3-1)

*2 正員, 東京大学大学院工学系研究科 (科学技術振興機構さきがけ $7332-0012$ 埼玉県川口市本町 4-1-8)

E-mail of corresponding author: shiomi@photon.t.u-tokyo.ac.jp 
ことから，高温域での実用化に向けた熱電変換材料として期待されている. その一方で，既存の熱電変換材料に 比べて高い格子熱伝導率を有するため（Kimura, et al., 2009), それを低減させることが最大の課題となっている.

これに対して，近年，合金化とナノ構造化を組み合わせた手法によって熱伝導率を低減することに成功してい る. 特に元素 X を Ti, Zr または Hf として, p 型では XCoSb (Yan, et al., 2011), n 型ではXNiSn (Uher, et al., 1999) の研究が急速に進んでおり，X を同族原子で置換合金化してフォノンの散乱を促すことで性能が向上している. $\mathrm{n}$ 型については，合金効果を用いた $\mathrm{Hf}_{0.75} \mathrm{Zr}_{0.25} \mathrm{CoSb}_{0.975} \mathrm{Sn}_{0.025}$ で ZT=0.8 (1025 K)（Culp, et al., 2006), さらにナノ構造 化することによって $Z T=1.0$ (900-1000 K)が達成されている (Joshi, et al., 2011). 一方, p 型については従来 $\mathrm{Hf}_{0.5} \mathrm{Zr}_{0.5} \mathrm{CoSb}_{0.8} \mathrm{Sn}_{0.2}$ が $Z T=0.5(1000 \mathrm{~K})$ （Culp, et al., 2008）と $\mathrm{n}$ 型と比較して小さかったが，最近になって，ナノ構 造化と組み合わせた $\mathrm{Hf}_{0.8} \mathrm{Ti}_{0.2} \mathrm{CoSb}_{0.8} \mathrm{Sn}_{0.2}$ によって, $Z T=0.9$ (1000 K)が達成されている（Yan, et al., 2012). これは, $\mathrm{Hf}_{1-x} \mathrm{Ti}_{x} \mathrm{CoSb}_{0.8} \mathrm{Sn}_{0.2}$ の混合比 $x$ を最適化することによって達成されたものであるが, 特筆すべきは, 非経験ボテン シャルを用いた分子動力学計算によって設計指針を得ている点にある. これは, 多くの材料開発が経験的に行わ れて来た中で，分子論に立脚した解析技術を利用して材料開発プロセスを大幅に効率化できる可能性を示してい る. 本研究はこの先行研究を踏襲して比較的性能の劣る $\mathrm{p}$ 型の合金効果の性能向上をさらに進めることを目的と する. 具体的には, 先行研究が元素 Xの置換を前提としていたのに対して, 本研究では X, Y, Z の中で置換を 施すのに最適な元素を電子状態にもとづいて決定するところから始める. 最適化の指針として，ハーフホイスラ 一化合物の高いパワーファクターを維持するべく，できるだけ電子状態を変化させずに合金化することとする. そのために，まずフェルミ準位近傍の電子状態への寄与の小さい元素を同定し，次にその元素を合金化した際の 熱伝導率の低減効果を評価することで，パワーファクターと熱伝導率を両立する組成を明らかにする.

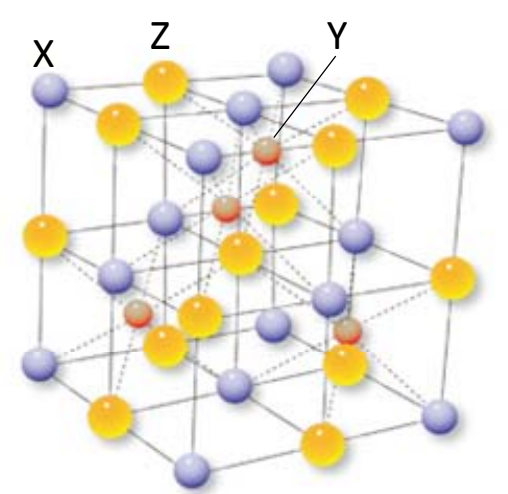

Fig. 1 A conventional unit cell of a half-Heusler compound. Atomic coordinates of X, Y, and Z are respectively $(0,0,0) a_{\text {lat }}$, $(1 / 4,1 / 4,1 / 4) a_{\text {lat, }}$ and $(1 / 2,1 / 2,1 / 2) a_{\text {lat. Here }} a_{\text {lat }}$ denotes a lattice constant.

\section{2. 制御元素の選択}

\section{$2 \cdot 1$ 電子状態計算}

密度汎関数理論にもとづく第一原理計算によって $\mathrm{ZrCoSb}$ ハーフホイスラー化合物の電子状態を求めた. 基底 状態の全エネルギ一最小化計算より格子定数は $6.10 \AA$ と求まり, 実験值(Sekimoto, T, et al., 2007) と良く一致した

（表 1)。なお，第一原理計算にはVASP パッケージ（Kresse and Furthmüller, 1994）を使用し，電子の交換相関エ ネルギーには一般化密度勾配近似(Generalized Gradient Approximation, GGA)を用いた．次に，計算によって得られ たフェルミエネルギー $\left(E_{\mathrm{f}}\right)$ 近傍における電子状態密度(Density of States, DOS)を図 2(a)に示寸. 加えて, 化合物 中の各元素 (Zr, Co, および Sb) 寄与を Local Partial DOS (L-PDOS)として図 2(b), (c), および(d)にそれぞれ示す. なお, 各元素の寄与は $\mathrm{s}$ (青), $\mathrm{p}$ (緑), および $\mathrm{d}$ (赤) 軌道の寄与に分けて示してある (Partial DOS). 図 2 から, どの軌道においても，Sbのフェルミエネルギー近傍の電子状態密度への影響は極めて小さく, Co による寄与が 総じて大きい傾向にあることがわかる.このことから, Co を元素置換すると, 微量であっても電気的物性に大き な変化をもたらすことが予測される，また，興味深いことに, Sb の方が Zr よりもフェルミエネルギー近傍の電 
子状態密度への寄与が小さいことから，置換サイトとしては，研究例（Xia, et al., 2000）が多い Zr よりも， $\mathrm{Sb} の$ 方が適していることが示唆される．電子状態を変化させることは必ずしも悪いことではなく，パワーファクター が向上寸る可能性も考えられるが，本研究では電気的物性を維持しながら熱伝導率を低減させることを目的とし ているため, Sb サイトを同族元素で質量置換することを設計指針として解析を進める. 置換元素の候補としては, N, P, As, Sb, Bi があるが, この中で安定相が確認されているのはZoCoBi だけである (Ponnambalam, et al., 2007). 本研究では, 重元素置換である $\mathrm{ZoCoSb}_{1-x} \mathrm{Bi}_{x}$ に加えて, 軽元素で置換した場合の効果を理論的に検証するために $\mathrm{ZoCoSb}_{1-x} \mathrm{As}_{x}$ も合わせて計算した.

Table 1 Comparison of lattice constants obtained by calculations and experiments (Sekimoto, et al., 2007;Yang, et al., 2008) .

\begin{tabular}{|l|c|c|c|}
\hline & $\mathrm{ZrCoAs}$ & $\mathrm{ZrCoSb}$ & $\mathrm{ZrCoBi}$ \\
\hline Calculation & $5.84 \AA$ & $6.10 \AA$ & $6.23 \AA$ \\
\hline Experiment & & $6.07 \AA$ & $6.19 \AA$ \\
\cline { 2 - 4 } & &
\end{tabular}

(a) Overall

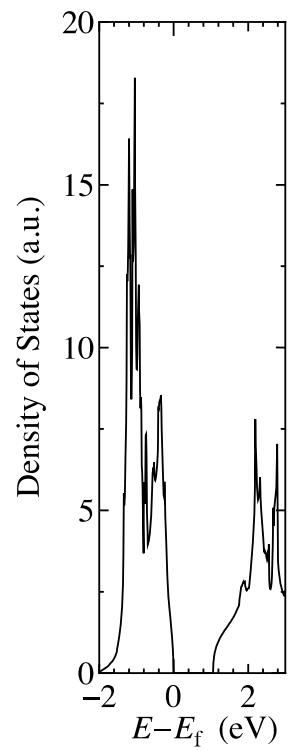

(b) $\mathrm{Zr}$

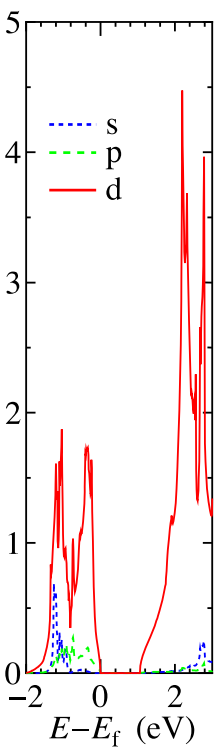

(c) $\mathrm{Co}$

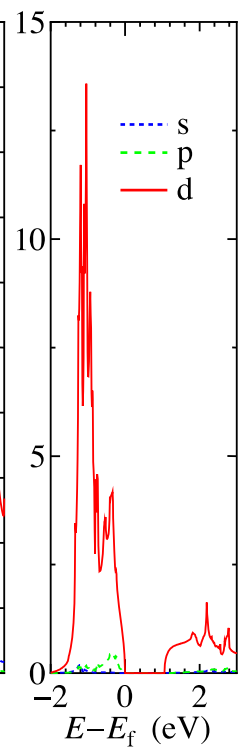

(d) $\mathrm{Sb}$

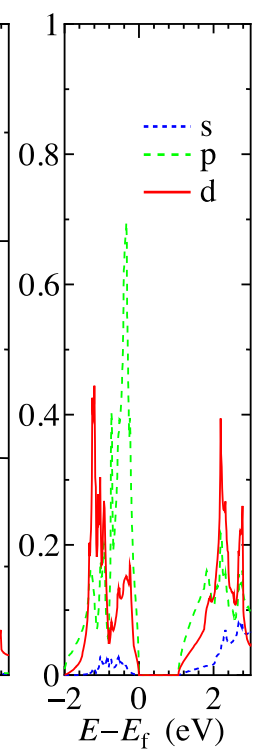

Fig. 2 Electron density of states (DOS) of $\mathrm{ZrCoSb}$ Half-Heusler compound; (a) is the overall DOS, and (b), (c), and (d) are the local-partial DOS of Zr, Co, and Sb elements, respectively.

\section{$2 \cdot 2$ 電子輸送係数}

$\mathrm{Sb}$ サイトを $\mathrm{Bi}$ や As で置換した際のパワーファクター $\left(S^{2} \sigma\right)$ への影響を評価するために, 第一原理的に得ら れた $\mathrm{ZrCoAs}, \mathrm{ZrCoSb}, \mathrm{ZrCoBi}$ のバンド構造をもとに電気伝導率 $\sigma$ およびゼーベック係数 $S$ を計算した. 計算は, Boltzmann Transport Properties (BoltzTrap) パッケージ（Gerog and Singh, 2006）を用いて行い，緩和時間近似を施し たボルツマン輸送方程式の解に基づいて行った. 第一原理計算においては, 表 1 に示すように $\mathrm{ZrCoBi}$ の格子定 数も実験值（Yang, et al., 2008）と良く一致した．なお，ZrCoAsについての実験值は報告されていないが，イオン 半径が小さいほど格子定数が小さくなる傾向と矛盾しない.

緩和時間近似を施したボルツマン輸送方程式によれば，電気伝導率のエネルギースペクトル密度は次式で与え られる。

$$
\bar{\sigma}_{\alpha \beta}(\varepsilon)=\frac{e^{2}}{N} \sum_{i, \mathbf{k}} \tau_{i, \mathbf{k}} v_{\alpha}(i, \mathbf{k}) v_{\beta}(i, \mathbf{k}) \frac{\delta\left(\varepsilon-\varepsilon_{i, \mathbf{k}}\right)}{d \varepsilon}
$$


ここで $\alpha, \beta$ は座標成分, $i$ は電子バンドの番号, $\mathbf{k}$ は波数ベクトル,$N$ は $\mathbf{k}$ 点の総数, $e$ は電気素量, $\tau$ は電荷キ ヤリアの緩和時間， $\varepsilon$ はバンドエネルギーを示寸，また，群速度 $v$ は,

$$
v_{\alpha}(i, \mathbf{k})=\frac{1}{\hbar} \frac{\partial \varepsilon_{i, \mathbf{k}}}{\partial k_{\alpha}}
$$

と表される. ちはプランク定数である. 式(1)を用いることで，電気伝導率テンソル $\sigma_{\alpha \beta}$ は温度 $T$ ，フェルミ準位 $\mu$ の関数として以下のように記述できる.

$$
\sigma_{\alpha \beta}(T, \mu)=\frac{1}{\Omega} \int \bar{\sigma}_{\alpha \beta}(\varepsilon)\left[-\frac{\partial f(T, \varepsilon, \mu)}{\partial \varepsilon}\right] d \varepsilon
$$

式(3)中の $\Omega$ は単位胞の体積を， $f$ はフェルミディラック分布関数をそれぞれ示す．同様に，ゼーベック係数テン ソル $S_{\alpha \beta}$ は下のように記述できる.

$$
S_{\alpha \beta}(T, \mu)=\frac{1}{e T \Omega \sigma_{\alpha \beta}(T, \mu)} \int \bar{\sigma}_{\alpha \beta}(\varepsilon)(\varepsilon-\mu)\left[-\frac{\partial f(T, \varepsilon, \mu)}{\partial \varepsilon}\right] d \varepsilon
$$

得られた結果を Rigid Band Approximation（RBA）（Scheidemantel, et al., 2003）に基づいて評価した．RBA ではド ーピングによってバンド構造は変化せず，フェルミ準位のみが変化する。これは少量のドーピングであれば妥当 であり, 熱電変換材料の分野で広く用いられている（Scheidemantel, et al., 2003; Chaput, et al., 2005; Gao, et al., 2005; Bilc, et al., 2005)。一方，輸送係数計算において重要となる緩和時間は，一般的に電子のエネルギーに強く依存す るものの, 輸送に寄与寸る電子のエネルギー分布はフェルミディラック分布関数のエネルギー微分( $(-\partial f / \partial \varepsilon)$ にっ て, フェルミ準位近傍に限定されるため, 電気伝導率およびゼーベック係数に大きく影響を与えないことが知ら れている(Chaput, et al., 2005). したがって, 本計算では緩和時間 $\tau$ はエネルギーに依存しない定数として取り扱っ た.

温度 $300 \mathrm{~K}$ で得られた各物性值を図 3 に示す．横軸はドーピングを想定したフェルミ準位の推移であり，バン ドギャップの中心を基準としている．なお，図 3 の破線は，各化合物のパワーファクター $\left(S^{2} \sigma / \tau\right)$ がバンドギャ ップ付近でピーク值を取る際のフェルミ準位を示している.この破線上における $S, \sigma / \tau, S^{2} \sigma / \tau$ の值を表 2 に示寸. 図 3 から，ゼーベック係数はバンドギャップの中央付近で大きな值を有することがわかる．しかし状態密度が極 めて小さいことから電気伝導率が小さく, 結果的にパワーファクターが小さい. また, フェルミ準位が価電子帯 または伝導帯の内部に推移するに従って電気伝導率が上昇する一方で，ゼーベック係数は減少する．これらを合 わせて, フェルミ準位が価電子帯の頂上付近に位置するときに最大のパワーファクターが得られることが分かる (最適ドーピング)。この結果から，これらの材料が $\mathrm{p}$ 型半導体に適していることが分かる.

緩和時間 $\tau$ が材料に依らないと仮定すると, 最適ドーピングの際の電気伝導率は $\mathrm{ZrCoBi}$ が最も大きい. これは $\mathrm{ZrCoBi}$ の方が ZrCoSbよりも電気伝導率が大きいという実験結果 (Poon, 2001; Ponnambalam, et al., 2007) と矛盾 しない, パワーファクターの最大值は ZrCoAs, $\mathrm{ZrCoSb}, \mathrm{ZrCoBi}$ の順で大きくなることが見積もられる一方で, 最適ドーピング近傍のパワーファクターの分布も考慮すると, それらの差はさほど大きくなく, $\mathrm{ZrCoSb}$ の Sb サ イトを元素置換した際のパワーファクターへの影響が限定的であることが確認できた.

Table 2 Thermoelectric properties of half-Heusler compounds with optimal doping.

\begin{tabular}{|c|c|c|c|}
\hline & ZrCoAs & ZrCoSb & ZrCoBi \\
\hline$S(\mu \mathrm{V} / \mathrm{K})$ & 131 & 121 & 115 \\
\hline$\sigma / \tau\left(10^{19} \mathrm{~S} / \mathrm{m} / \mathrm{s}\right)$ & 6.9 & 8.8 & 12.7 \\
\hline$S^{2} \sigma / \tau\left(10^{12} \mathrm{~W} / \mathrm{m}-\mathrm{K}^{2} / \mathrm{s}\right)$ & 1.19 & 1.29 & 1.67 \\
\hline
\end{tabular}



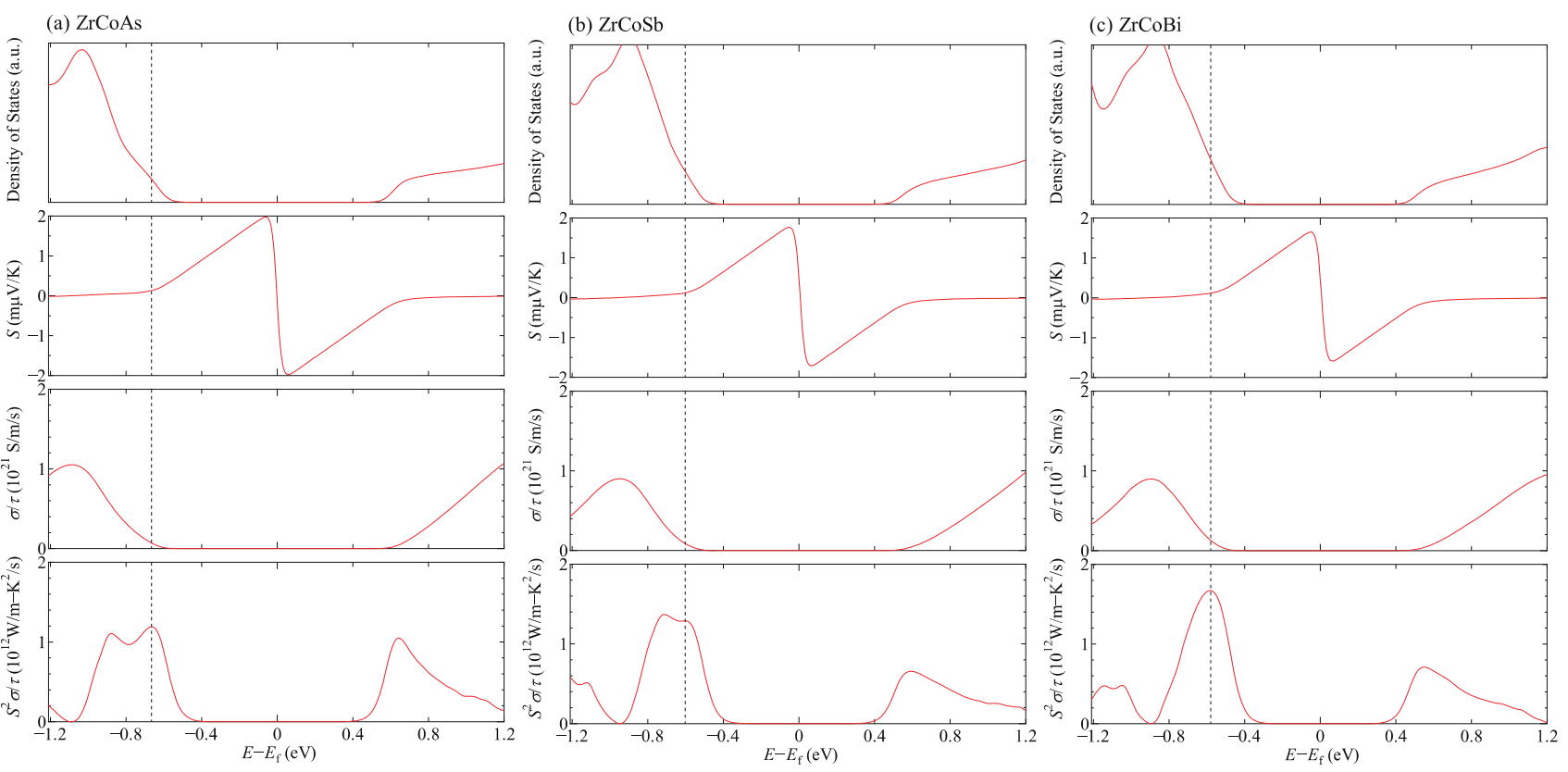

Fig. 3 Density of states (DOS), Seebeck coefficient $(S)$, electrical conductivity $(\sigma / \tau)$, and power factor $\left(S^{2} \sigma / \tau\right)$ of (a) $\mathrm{ZrCoAs}$, (b) $\mathrm{ZrCoSb}$, and (c) $\mathrm{ZrCoBi}$, at $300 \mathrm{~K}$.

\section{3 格子熱伝導率の低減効果}

\section{$3 \cdot 1$ 格子熱伝導率解析}

以上を踏まえて, $\mathrm{ZrCoSb}$ の $\mathrm{Sb}$ サイトを $\mathrm{As}$ または $\mathrm{Bi}$ で合金化した $\mathrm{ZrCoSb}_{1-x} \mathrm{As}_{x}$ と $\mathrm{ZrCoSb}_{1-x} \mathrm{Bi}_{x}$ について熱伝導 率を計算した. 熱電変換材料の $Z T$ は熱伝導率に反比例するため, 数 $10 \%$ の格子熱伝導率の変化であっても効率 に大きな影響を与えることから，定量的な $Z T$ のためには正確な熱伝導率の評価が要求される．しかし，格子熱 伝導率の計算には半経験的なポテンシャルが用いられることが多く, ほとんどの場合は非調和性が最適化されて いないことから，格子熱伝導率を正確に再現する保証はない．それに対して近年，第一原理から非調和原子間力 定数を非経験的に計算し，それを用いて格子熱伝導率を計算する手法が急速に発展してきている（Esfarjani, et al., 2011; Shiomi, et al., 2011). 格子熱伝導率の計算手法として, 主に格子動力学法と分子動力学法が挙げられる. 格 子動力学法はフォノンを平面波として取扱う逆格子空間解析法であるため，合金結晶のようにランダムな分布で 局所的に質量が変動する構造を取り扱うのが得意ではない，一方で，分子動力学法は実空間法であるため局所的 構造が取扱いやすいメリットがある. したがって本研究では, 多項式型の非調和原子間力場を用いた分子動力学 法によって格子熱伝導率を評価する，なお，ここで採用する古典分子動力学ではニュートンの運動方程式を支配 方程式とするため, 量子統計を考慮することはできないが，八ーフホイスラー化合物をはじめとする多くの熱電 変換材料のデバイ温度は比較的低いため, 室温以上の温度領域では古典近似が妥当であることがわかっている

(Shiomi, J. et al., 2011).

力場は, 各原子の平衡位置からの変位 $u$ に対して次式のように表す.

$$
-F_{i}^{\alpha}=\sum_{j, \beta} \Phi_{i j}^{\alpha \beta} u_{j}^{\beta}+\frac{1}{2 !} \sum_{j k, \beta k} \Psi_{i j k}^{\alpha \beta \gamma} u_{j}^{\beta} u_{k}^{\gamma}+\frac{1}{3 !} \sum_{j k l, \beta k l} \mathrm{X}_{i j k l}^{\alpha \beta \gamma \delta} u_{j}^{\beta} u_{k}^{\gamma} u_{l}^{\delta}
$$

ここで係数 $\Phi, \Psi, \mathrm{X}$ は各次数における原子間力定数である.また, $i, j, k, l$ は原子の番号を, $\alpha, \beta, \gamma, \delta$ は直 交座標を示す．原子力間定数には，第一原理計算にもとづく実空間変位法（Esfarjani and Stokes, 2008）によって 得られたもの（Shiomi, et al., 2011）を用いた. なお, $\mathrm{ZrCoAs}, \mathrm{ZrCoSb}, \mathrm{ZrCoBi}$ の原子力間定数が等しいと仮定し, 


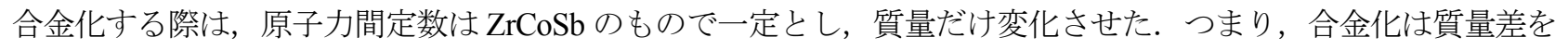
通じてのみ熱伝導率に影響する。この手法は $\mathrm{Hf}_{x} \mathrm{Zr}_{1-x} \mathrm{CoSb}$ の熱伝導率の合金割合への依存性を定量的に再現する ことが確認されている（Shiomi, et al., 2011）。このような非調和原子間力定数の相似性は，ハーフホイスラー化合 物だけでなく，シリコンとゲルマニウムなどに関してもわかっている（Murakami, et al., 2014）。なお，As， Sb， Bi の原子質量はそれぞれ $74.92 \mathrm{amu}, 121.76 \mathrm{amu}, 208.98 \mathrm{amu}$ である.

分子動力学法を用いて熱伝導率を計算する手法はいくつかあるが (Shiomi, 2014), 本研究では平衡分子動力学 法を用いた．計算系としては，格子定数 $6.10 \AA$ の慣用単位胞を $5 \times 5 \times 5$ となるように配置した（原子数 $1,500 ） 3$ 次元周期境界系を取り扱った．合金割合は $1 \%, 2 \%, 5 \%, 10 \%, 25 \%, 50 \%, 100 \%$ とし，各合金割合に対し て 3 通り $(100 \%$ のきは 1 通り)の原子配置をランダムに作成し, それぞれの原子配置に対して初期条件の異なる 10 通りのシミュレーションを行った。温度は $300 \mathrm{~K}$ とし, 温度制御下で系の構造を緩和させた後に, 温度制御を 止めてエネルギー一定（ミクロニカルアンサンブル）でさらに緩和させ，平衡状態に至った後に $1 \mathrm{~ns}$ のシミュレ ーションを行い，熱流束の時系列を計測した．得られた熱流束 $\mathbf{J}$ の自己相関関数のアンサンブル平均をもとに， 格子熱伝導率を以下のようにグリーン・久保公式を用いて計算した.

$$
\kappa=\frac{V}{3 k_{B} T^{2}} \lim _{t^{\prime} \rightarrow \infty} \int_{0}^{t^{\prime}}\langle\mathbf{J}(0) \cdot \mathbf{J}(t)\rangle d t
$$

ここで， $k_{\mathrm{B}}$ はボルツマン定数，Vは計算セルの体積である.

\section{$3 \cdot 2$ 格子熱伝導率への合金化効果}

得られた熱伝導率の合金割合への依存性を図 4 亿示す。この結果から, Sb サイトを Bi で置換することによっ て, p 型ハーフホイスラー化合物の格子熱伝導率を $15 \%$ 以下まで低減できる可能性が示された. また, 格子熱伝 導率の合金割合 $x$ に対する勾配の絶対值は $x$ が小さいほど大きく,$x=20 \%$ を超える勾配は殆どゼロとなり,$x$ を増 加させても熱伝導率は変わらない. したがって, 実際の合金化材料を開発する際は $x=20 \%$ 目安とすることが推 奨される.

また，図４から，Bi と As を同じ割合だけ置換したときの熱伝導率を比較した場合，前者の方が熱伝導率が小 さくなることが見てとれる，一方，既報の $\mathrm{Hf}_{\mathrm{x}} \mathrm{Zr}_{1-\mathrm{x}} \mathrm{CoSb}$ （Shiomi, et al., 2011） と今回の $\mathrm{Zr}_{1-\mathrm{x}} \mathrm{CoSb}_{1-\mathrm{x}} \mathrm{Bi}_{\mathrm{x}}$ を比較する と, 合金割合が $50 \%$ \%きの值がほぼ等しく, そのほかの割合についても似たような挙動を示している.さらに, 既報の $\mathrm{Ti}_{\mathrm{x}} \mathrm{Zr}_{1-\mathrm{x}} \mathrm{CoSb}$ と今回の $\mathrm{ZrCoSb}_{1-\mathrm{x}} \mathrm{As}_{\mathrm{x}}$ を比較しても熱伝導率が概ね一致している. フォノンの合金散乱の強 度に影響する質量差の観点から考えると, $\mathrm{Bi}$ と $\mathrm{Sb}$ の差（原子量差 87.22）が $\mathrm{Hf}$ と $\mathrm{Zr}$ の差（原子量差 87.27） と ほぼ等しく, Sb と As の差（原子量差 46.84）が Zr と Ti の差（原子量差 43.34）と概ね等しい. したがって, 得 られた熱伝導率低減効果の置換元素依存性の傾向は, 置換前後の原子量差によって定性的に説明できる. Sbを置 換する場合と Zr を置換する場合とでは置換サイトが異なるにも関わらず,このように整理できることが興味深い が，これは図 1 にあるように Zr と Sb は塩化ナトリウム型構造の等価な位置にあることによると考えられる.

\section{4. 結 言}

置換合金化による $\mathrm{p}$ 型ハーフホイスラー化合物（ $\mathrm{ZrCoSb})$ の性能指数向上に向けて，第一原理に基づいて電子 状態密度, 電気伝導率, ゼーベック係数, 格子熱伝導率の計算を行った. Z $\mathrm{rCoSb}$ を同族元素で置換合金化するこ とによって電子物性をできるだけ変えずに格子熱伝導率を低減することを念頭に電子状態計算を行ったところ, フェルミ準位近傍の電子状態への寄与が最も小さい元素が Sb であることを同定した. 加えて, $\mathrm{ZrCoBi}$ および仮 想 $\mathrm{ZrCoAs}$ の電気伝導率およびゼーベック係数の計算を行うことで, $\mathrm{Sb}$ を元素置換することによるパワーファク ターへの影響が小さいことを確認した。 さらに，第一原理に基づいて導出した非調和原子間力定数を用いた分子 動力学計算によって, 置換合金化が格子熱伝導率に与える影響を評価した. その結果, $\mathrm{ZrCoSb}_{1-x} \mathrm{Bi}_{x}$ の格子熱伝導 
率は $x \sim 20 \%$ において $15 \%$ 以下まで低減されることがわかった. $x$ を $20 \%$ より大きくしても低減効果はほとんど変 らないことから, $\mathrm{ZrCoSb}_{0.8} \mathrm{Bi}_{0.2}$ が熱電変換性能を改善するにあたって妥当な合金組成であることが同定した.
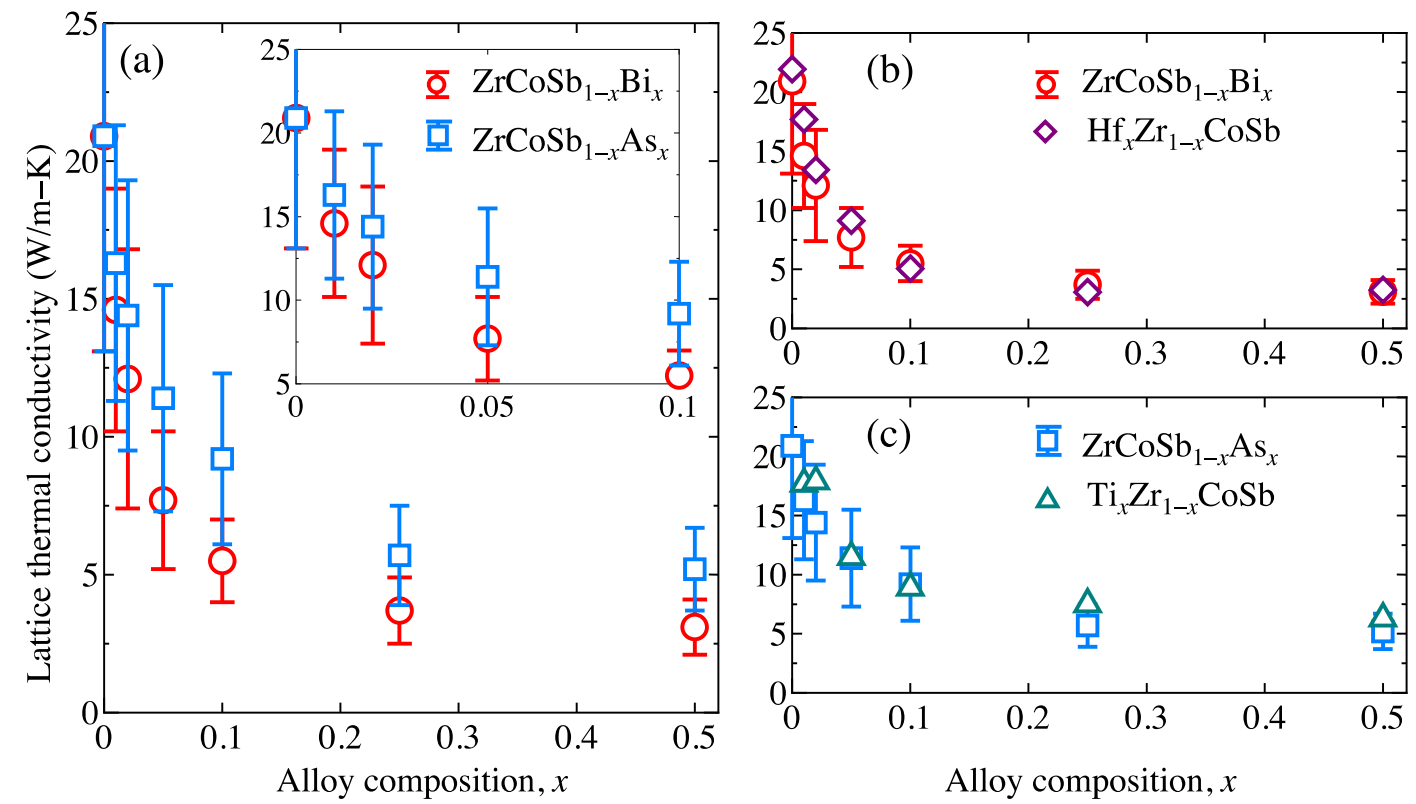

Fig. 4 Dependence of thermal conductivity of half-Heusler compounds on alloy fraction $x$ at $300 \mathrm{~K}$.

謝 辞

本研究の一部は, 科学技術振興機構戦略的創造研究推進事業 (さきがけ), および科学研究費補助金(2679009) の 補助によって行われた。

\section{References}

Bilc, D. I., Mahanti, S. D. and Kanatzidis, M. G., Electronic transport properties of PbTe and AgPbmSbTe2+m systems, Physical Review B, Vol. 74 (2005), p. 125202.

Culp, S. R., Poon, S. J., Hickman, N., Tritt, T. M. and Blumm, J., Effect of substitutions on the thermoelectric figure of merit of half-Heusler phases at $800^{\circ} \mathrm{C}$, Applied Physics Letters, Vol. 88 (2006), p. 042106.

Culp, S. R., Simonson, J. W., Poon, S. J., Ponnambalam, V., Edwards, J. and Tritt, T. M., (Zr,Hf)Co(Sb,Sn) half-Heusler phases as high-temperature $\left(>700^{\circ} \mathrm{C}\right)$ p-type thermoelectric materials, Applied Physics Letters, Vol. 93 (2008), p. 022105 .

Chaput, L., Pécheur, P., Tobola, J. and Scherrer, H., Transport in doped skutterudites: Ab initio electronic structure calculations, Physical Review B, Vol. 72 (2005), p. 085126.

Esfarjani, K., and Stokes, H. T., Method to extract anharmonic force constants from first principles calculations, Physical Review B, Vol. 77 (2008), p. 144112.

Esfarjani, K., Chen, G. and Stokes, H. T., Heat Transport in silicon from first-principles calculation, Physical Review B, Vol. 84 (2011), p. 085204.

Gao, X., Uehara, K., Klug, D. D., Patchkovskii, S., Tse, J. S. and Tritt, T. M., Theoretical studies on the thermopower of semiconductors and low-band-gap crystalline polymers, Physical Review B, Vol. 72 (2005), p. 125202.

Georg, G. K. H. and Singh, D. J., BoltztraP. A code for calculating band-structure dependent quantities, Computer Physics Communication, Vol. 175 (2006), pp. 67-71. 
Joshi, G., Yan, X., Wang, H., Liu, W., Chen, G. and Ren, Z., Enhancement in thermoelectric figure-of-merit of an n-type half-Heusler compound by the nanocomposite approach, Advanced Energy Materials, Vol. 1 (2011), pp. 643-647.

Kimura, Y., Ueno, H. and Mishima, Y., Thermoelectric properties of directionally solidified half-Heusler $\left(\mathrm{Ma}_{0.5}, \mathrm{Mb}_{0.5}\right) \mathrm{NiSn}$ (Ma, Mb= Hf, Zr, Ti) Alloys, Journal of Electronic Materials, Vol. 38 (2009), pp. 934-939.

Kresse, G. and Furthmüller, J., Efficient iterative schemes for ab initio total-energy calculations using a plane-wave basis set, Computational Materials Science, Vol. 6 (1994), pp. 15-50.

Murakami, T., Hori, T., Shiga, T. and Shiomi, J., Probing and tuning inelastic phonon conduction across finite-length interface, Applied. Physics Express, Vol. 7 (2014), p. 121801.

Ponnambalam, V., Zhang, B., Tritt, T. M. and Poon, S. J., Thermoelectric properties of half-Heusler bismuthides $\mathrm{ZrCo}_{1-x} \mathrm{Ni}_{\mathrm{x}} \mathrm{Bi}$ $(\mathrm{x}=0.0$ to 0.1$)$, Journal of Electronic Materials, Vol. 36 (2007), pp. 732-735.

Poon, S. J., Electronic and thermoelectric properties of half-Heusler alloys, Semiconductors and semimetals, Vol. 70 (2001) pp. 37-75.

Sekimoto, T., Kurosaki, K., Muta, H. and Yamanaka, S., High-thermoelectric figure of merit realized in p-type half-Heusler compounds: $\mathrm{ZrCoSn}_{\mathrm{x}} \mathrm{Sb}_{1-\mathrm{x}}$, Japanese Journal of Applied Physics, Vol. 46 (2007), pp. 673-675.

Scheidemantel, T. J., Draxl, C. A., Thonhauser, T., Badding, J. V. and Sofo, J. O., Transport coefficients from first-principles calculations, Physical Review B, Vol. 68 (2003), p. 125210.

Shiomi, J., Esfarjani, K. and Chen, G., Thermal conductivity of half-Heusler compounds from first-principles calculations, Physical Review B, Vol. 84 (2011), p. 104302.

Shiomi, J., Nonequilibrium molecular dynamics methods for heat conduction calculations, Annual Review of Heat Transfer, Vol. 17 (2014), pp. 177-203.

Uher, C., Yang, J., Hu, S., Morelli, D. T. and Meisner, G. P., Transport properties of pure and doped MNiSn (M=Zr, Hf), Physical Review B, Vol. 59 (1999), pp. 8615-8621.

Xia, Y., Bhattacharya, S., Ponnambalam, V., Pope, A. L., Poon, S. J. and Tritt, T. M., Thermoelectric properties of semimetallic (Zr, Hf)CoSb half-Heusler phases, Journal of Applied Physics, Vol. 88 (2000), pp. 1952-1955.

Yan, X., Joshi, G., Liu, W., Lan, Y., Wang, H., Lee, S., Simonson, J. W., Poon, S. J., Tritt, T. M., Chen, G. and Ren Z. F., Enhanced thermoelectric figure of merit of p-type half-Heuslers, Nano Letters, Vol. 11 (2011), pp. 556-560.

Yan, X., Liu, W., Wang, H., Chen, S., Shiomi, J., Esfarjani, K., Wang, H., Wang, D., Chen, G. and Ren, Z., Stronger phonon scattering by larger differences in atomic mass and size in p-type half-Heuslers $\mathrm{Hf}_{1-\mathrm{x}} \mathrm{Ti}_{\mathrm{x}} \mathrm{CoSb}_{0.8} \mathrm{Sn}_{0.2}, \mathrm{Energy}_{\mathrm{B}}$ \& Environmental Science, Vol. 5 (2012), pp. 7543-7548.

Yang, J., Wu, H. Li, T., Zhang, W., Chen, L. and Yang, J., Evaluation of half-Heusler compounds as thermoelectric materials based on the calculated electrical transport properties, Advanced Functional Materials, Vol. 18 (2008), pp. 2880-2888. 